\title{
SELF-OBSERVATION VERSUS FLOODING IN THE TREATMENT OF AGORAPHOBIA*
}

\author{
PALL M. G. EMMELKAMP \\ Institute for Clinical and Industrial Psychology. Trans 4, Utrecht. The Netherlands
}

(Reciled 7 . Hurch $197+1$

\begin{abstract}
Summary-The effects on agoraphobia of (1) self-observation with a minimum of therapeutic intervention. (2) flooding. (3) a combination of flooding and self-observation, and (4) no-treatment control were compared. Assessments were made at the beginning of treatment. during and at the end of treatment and at the follow-up three months later. They were carried out by the therapist (in vico measurement: phobic anxicty and phobic avoidance scale) by an independent observer (phobic anxiety scale and phobic a voidance scale) and by the client (phobic anxiety scale; phobic a voidance scale; FSS; social anxiety scale; SDS and I-E scale).

Self-observation. Hooding and flooding self-observation resulted in significant improvement on several variables, whereas the no-treatment control group did not improve. No difference in effectiveness was found between the self-observation and flooding treatments. In addition. the results suggest that a combined flooding/self-observation treatment is more effective than each of the individual treatments.
\end{abstract}

Generally speaking, systematic desensitization has been found to have little effect in the treatment of agoraphobia (Marks, 1969), although not all behaviour therapists agree with this statement (Gelder et al.. 1973). The results of recent investigations suggest that flooding (Hand et al., 1974; Marks et al., 1971; Stern and Marks. 1973; Watson and Marks, 1971) and shaping or successive approximation (Agras et al., 1968) are more adequate treatments for agoraphobia. Successive approximation and flooding were found to be equally effective with phobic clients (Crowe et al., 1972) and with agoraphobics (Everaerd et al., 1973).

With successive approximation, the clients are given both social reinforcement and feedback for the time spent in the phobic situation. Emmelkamp and Ultee (1974) compared successive approximation and a self-observation method in a group of agoraphobics. With the self-observation method, the clients themselves record the time they spend outside without feeling tense (feedback), but they do not receive reinforcement from the therapist. Self-observation and successive approximation proved to be equally effective methods.

In the investigation by Emmelkamp and Ultee (1974). the therapist was present at each session. Thus it was not clear whether the self-observation method would be equally effective if the therapist were present at the first few sessions only. If this should prove to be the case. it would mean that the intervention of the therapist could be reduced, and that the client could partly carry out his own treatment. Moreover, it was hypothesized that

\footnotetext{
* A grant from Netherlands Organization for the Advancement of Pure Research (Z.W.O. no. 58-20) made this study possible. We wish to thank Kees Boersma, Edzar Bosch van Rosenthal, Simon den Hengst, Peter Prins, Carel Sallaerts. Paul Schreurs en Hemmy Wessels for their assistance in the treatment of the clients and Maarten van Son serving as an independent observer.

Request for reprints should be sent to P. Emmelkamp. Institute for Clinical and Industrial Psychology, Trans 4. Utrecht the Netherlands.
} 
after a few flooding sessions. given at the start of the treatment. the client could carry out the self-observation procedure more successfully. In order to investigate this, the effects of the following methods for treating agoraphobia were compared: (1) self-observation with a minimum of therapeutic intervention. (2) flooding. (3) a combination of flooding and self-observation. and (4) a no-treatment control.

\section{De'sign}

The first nine clients who qualified for treatment were given a pre-test and put on a waiting list. After one month a post-test followed, and these clients were split up into groups according to the treatment they were to receive. These clients were matched according to the following variables: duration of time they were able to walk around in the streets alone; sex; duration of complaint. The other clients were also matched, and then placed into groups according to the treatment they were to receive: (1) flooding: twelve flooding sessions. three before and nine after the intermediate test, (2) self-observation; twelve self-observation sessions, three before and nine after the intermediate test, (3) flooding/self-observation: three flooding sessions after the intermediate test followed by nine self-observation sessions. After completion of the three treatments the post-test assessments were made and 3 months later, a follow-up was conducted.

\section{Treatments}

The home of the client was used as the starting point in the treatment (cf. Everaerd et al. 1973; Emmelkamp and Ultee, 1974).

As a rule there were three sessions of 90 min each, per week.

\section{FLOODING}

The first session was spent in making a list of the phobic situations and their relevant cues. It was also ascertained how vividly the client was able to imagine both neutral situations (e.g. the living room) and phobic situations (e.g. the street). The sessions that followed consisted of $45 \mathrm{~min}$ of flooding in the imagination, immediately followed by $45 \mathrm{~min}$ of flooding in vico. With flooding in the imagination, the client was instructed to sit as comfortably and relaxed as possible and to close his eyes. Next, the therapist asked the

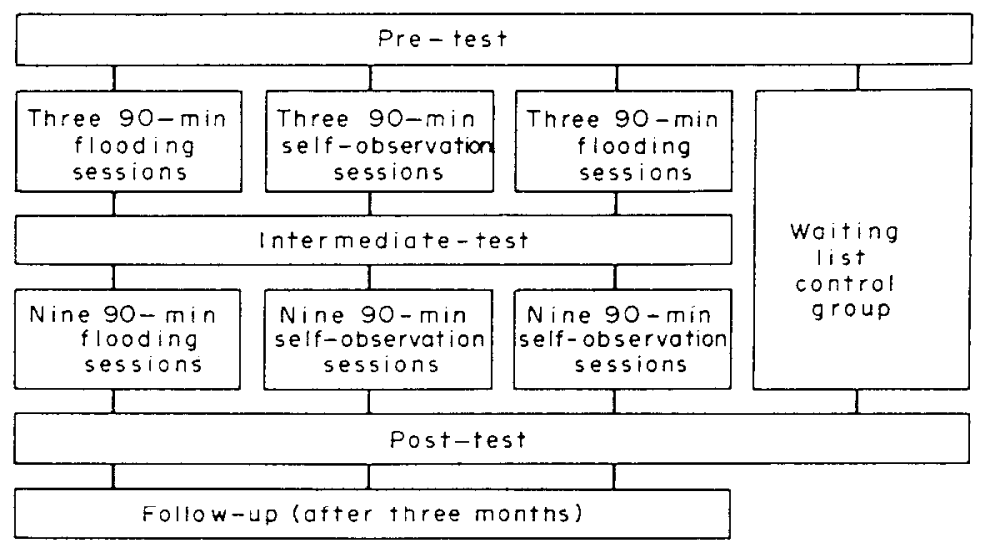

Fig. 1 . 
client to imagine the situations described by the therapist as vividly as possible, and not to banish these scenes from his imagination. Those situations which aroused the greatest anxiety were described to the client; for example, walking in the street alone, sitting in a crowded room, or travelling by bus. train or car.

Variations in the situations were introduced if, on inquiry, it appeared that certain situations no longer aroused anxiety. No psychodynamic cues were included in the scenes.

The $45 \mathrm{~min}$ of flooding in the imagination were immediately followed by $45 \mathrm{~min}$ of flooding in vico: the client had to walk in the streets, on his own. along a route which he and his therapist had jointly determined.

\section{SELF OBSERVATION}

The technique involves a graduated approach by the subject into the actual feared situation, with instructions to turn back on experiencing undue anxiety. In fact, this procedure is a modification of successive approximation. The differences with the latter procedure are that in self-observation the client observes his progress by recording the time he is able to spend outside without feeling tense and that he never is reinforced by his therapist.

Right from the first session, the client had to enter the phobic situation. Therapist and client agreed upon a route through the city, pretty difficult for the client, leading in a straight line from his home. The client had to walk alone without any aid which might reduce anxiety (e.g. umbrella, bicycle, hand-bag, sunglasses, dog, etc.). The same rule applied to clients treated by flooding. He was given the following instructions: "You must now go into the street and stay outside until you begin to feel uncomfortable or tense. As soon as you_no longer feel happy, you must come back straight away." The client had to record the duration of each trial. After returning home for the first time he had to write down the duration in a note-book. Then he had to enter the phobic situation in the same way. This procedure was repeated until the $90-\mathrm{min}$ session was over. The therapist was present only at the first five sessions, and had been instructed to occupy himself with work of his own and to interfere with the activities of the client as little as possible.

After five sessions the client had to carry on alone. At the end of each trial he had to note down the time spent outside without feeling tense, and he had to send the results to his therapist at the end of each session. After seven 'homework' sessions the post-test was applied.

\section{FLOODING/SELF-OBSERVATION}

In the first three sessions the client was given the flooding treatment. In this case too, each session consisted of $45 \mathrm{~min}$ of flooding in the imagination, immediately followed by $45 \mathrm{~min}$ of flooding in vivo. After the intermediate test, the client was treated with the selfobservation method.

The therapist was present only at the first two sessions with the self-observation method. This means that both in the case of the self-observation treatment and in the case of the flooding/self-observation treatment, the therapist was present at only five sessions altogether. After seven 'homework' sessions, the post-test was applied.

\section{WAITING-LIST CONTROL GROLP}

Only a pre-test and a post-test were performed with this group. There was no contact between the client and the therapist during the intervening period: the client was told that there was no possibility of treatment for some time. 


\section{Therapists}

The therapists in this investigation were either advanced clinical psychology students or psychologists who had just finished their studies; they were all versed in behaviour therapy. All the therapists were supervised by the author. Weekly group discussions were held at which difficulties connected with the treatments were discussed.

\section{Clients}

Twenty-nine clients took part in the experiment, 18 women and 11 men. During the first phase of treatment, three clients decided not to continue with the treatment. leaving 16 women and $10 \mathrm{men}$. Their average age was $43.9 \mathrm{yr}$, ranging from 22 to $69 \mathrm{yr}$. The average duration of the complaint was $9.2 \mathrm{yr}$, ranging from 1 to $49 \mathrm{yr}$.

After the intermediate test. 2 clients dropped out because of illness, and another 4 because they could not meet the methodological demands of the experiment.

Thus of the original twenty-nine subjects, thirteen women and seven men completed the treatment: four subjects from the flooding group dropped out, four from the self-observation group and one from the flooding/self-observation group.

\section{Assessments}

Assessments were carried out at the pre-test, intermediate test, post-test and the followup by the client and the therapist. In addition, an independent observer-a clinical psychologist-assessed the client at the beginning and the end of the treatment.

In vivo measurement. The client was instructed to go into the street and to stay outside until he began to feel uncomfortable or tense, then he had to come back straight away. The duration of time spent outside was measured by the therapist.

Phobic anxicty and avoidance scales. Client, therapist and indepdendent observer rated five phobic situations on 9-point scales for phobic anxiety and phobic avoidance respectively (Watson and Marks, 1971). The scores for the main phobia (street) were calculated separately; the scores for the other four phobias were added up.

Anxious mood and panic. Therapist and independent observer rated the client on 9-point scales for anxious mood and panic (Watson and Marks, 1971).

Table 1. Reliability across raters $(N=20)$

\begin{tabular}{lcccc}
\hline $\begin{array}{c}\text { Correlations } \\
\text { between }\end{array}$ & $\begin{array}{c}\text { Main phobia } \\
\text { Phobic } \\
\text { anxiety }\end{array}$ & $\begin{array}{c}\text { Phobic } \\
\text { avoidance }\end{array}$ & $\begin{array}{c}\text { Other phobias } \\
\text { Phobic } \\
\text { anxiety }\end{array}$ & $\begin{array}{c}\text { Phobic } \\
\text { avoidance }\end{array}$ \\
\hline Client-therapist & 0.53 & 0.62 & 0.74 & 0.73 \\
Client-observer & 0.62 & 0.55 & 0.71 & 0.69 \\
Therapist-observer & 0.59 & 0.54 & 0.70 & 0.74 \\
\hline
\end{tabular}

Moreover, the clients filled in the following questionnaires at the pre-test, the post-test and the follow-up: Fear Survey Schedule (FSS) (Wolpe and Lang, 1964; range 76-380); Social Anxiety Scale (SAS) (Willems et al., 1973; range 0-96); Internal-External Control Scale (I-E) (Rotter, 1966; range 12-71); and Self-rating Depression Scale (SDS) (Zung, 1965; range 23-92). Variations adapted for use in the Netherlands were used. 
Inter-obsercer reliability

Although the inter-observer reliabilities for the phobic anxiety and avoidance scales were fairly high, they were in general somewhat lower than in previous investigations (Emmelkamp and Ultee, 1974; Watson and Marks. 1971).

As the inter-observer reliabilities between therapist and independent observer for panic and anxious mood were low, $r=0.29$ and $r=0.24$ respectively, these scales were not included in the data analysis.

\section{RESULTS}

At the beginning of the treatment, a significant difference between the various conditions was found only on the SAS: the mean of the waiting-list control group was significantly lower than the mean of the self-observation group $(p<0.10)$ and significantly lower than that of the flooding/self-observation group $(p<0.05)$.

The effect of each individual treatment was tested with two-tailed $t$-tests for dependent samples.

Table 2. Effect of the individual treatments

\begin{tabular}{|c|c|c|c|c|c|c|c|}
\hline \multirow[b]{2}{*}{ Flooding } & & \multicolumn{2}{|c|}{ Pre-test } & \multicolumn{2}{|c|}{ Post-test } & \multirow[b]{2}{*}{$d f$} & \multirow[b]{2}{*}{ t } \\
\hline & & $\mathrm{M}$ & $\mathrm{SD}$ & $\mathbf{M}$ & $\mathrm{SD}$ & & \\
\hline In vivo measurement & & 10.1 & 5.6 & 46.9 & 23.9 & 6 & $-3.51\}$ \\
\hline Phobic anxiety scale & $\int \mathrm{C}$ & 59 & 1.3 & 3.0 & 1.7 & 6 & $3.23+$ \\
\hline \multirow[t]{3}{*}{ Street } & $\{0$ & 6.9 & 1.4 & 4.0 & 2.0 & 6 & $2.55 \dagger$ \\
\hline & $(T$ & 6.5 & 1.0 & 2.9 & 1.6 & 6 & $4.08_{+}^{+}$ \\
\hline & $C$ & 20.4 & 3.8 & 14.9 & 8.1 & 6 & $2.66^{*}$ \\
\hline \multirow[t]{2}{*}{ Other phobias } & $\{0$ & 25.0 & 3.5 & 18.7 & 8.3 & 6 & 2.15 \\
\hline & LT & 21.1 & 6.6 & 14.6 & 7.4 & 6 & $2.65^{*}$ \\
\hline \multicolumn{8}{|l|}{ Phobic avoidance scale } \\
\hline & $\int \mathrm{C}$ & 6.4 & 0.9 & 4.0 & 2.1 & 6 & $2.79 *$ \\
\hline \multirow[t]{3}{*}{ Street } & $\{0$ & 7.1 & 0.8 & 4.3 & 2.5 & 6 & $2 .+6^{*}$ \\
\hline & $(T$ & 7.1 & 0.6 & 4.1 & 1.7 & 6 & $3.33+$ \\
\hline & $\mathrm{C}$ & 25.7 & 2.9 & 19.0 & 9.2 & 6 & 213 \\
\hline \multirow[t]{2}{*}{ Other phobias } & \{ & 27.1 & 2.9 & 20.1 & 10.8 & 6 & 1.68 \\
\hline & $\mathrm{T}$ & 26.6 & 2.5 & 19.4 & 8.7 & 6 & 2.09 \\
\hline FSS & & 183.7 & 47.1 & 150.4 & 8.4 & 6 & 1.69 \\
\hline SAS & & 50.6 & 16.9 & 44.9 & 22.3 & 6 & 1.19 \\
\hline I-E scale & & 41.7 & 7.6 & 43.1 & 4.8 & 6 & -1.06 \\
\hline \multirow[t]{2}{*}{ SDS } & & 54.1 & 8.4 & 46.3 & 8.8 & 6 & 1.62 \\
\hline & & \multicolumn{2}{|c|}{ Pre-test } & \multicolumn{2}{|c|}{ Post-test } & & \\
\hline \multicolumn{2}{|l|}{ Self-observation } & $\mathrm{M}$ & $\mathrm{SD}$ & M & $\mathrm{SD}$ & $d f$ & $t$ \\
\hline \multicolumn{2}{|l|}{ In vivo measurement } & 10.6 & 7.0 & 45.4 & 26.6 & 6 & $-4.04+$ \\
\hline \multirow{4}{*}{$\begin{array}{l}\text { Phobic anxiety scale } \\
\text { Stretet }\end{array}$} & $\int \mathrm{C}$ & 6.3 & 1.6 & 2.6 & 1.3 & 6 & $5.46_{t}^{+}$ \\
\hline & 30 & 6.7 & 1.4 & 4.3 & 2.3 & 6 & $299^{*}$ \\
\hline & $\operatorname{lr}$ & 6.0 & 0.8 & 3.4 & 1.6 & 6 & $3.96+$ \\
\hline & $\mathrm{C}$ & 20.6 & 2.6 & 15.7 & 7.0 & 6 & 1.75 \\
\hline \multirow[t]{2}{*}{ Other phobias } & $\{0$ & 25.1 & 3.8 & 21.1 & 6.7 & 6 & 2.01 \\
\hline & 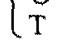 & 18.4 & 5.0 & 14.6 & 4.5 & 6 & $4.82+$ \\
\hline \multicolumn{8}{|l|}{ Phobic avoidance scale } \\
\hline \multirow{3}{*}{ Sereet } & $\mathrm{C}$ & 6.6 & 1.4 & 4.0 & 1.7 & 6 & $2.58^{*}$ \\
\hline & 0 & 7.0 & 1.4 & 49 & 1.9 & 6 & 2.17 \\
\hline & $T$ & 7.4 & 1.1 & 43 & 2.1 & 6 & $3.67 t$ \\
\hline
\end{tabular}


Table 2. Continued

\begin{tabular}{|c|c|c|c|c|c|c|c|}
\hline \multirow[b]{2}{*}{ Self-observation } & & \multicolumn{2}{|c|}{ Pre-test } & \multicolumn{2}{|c|}{ Post-test } & \multirow[b]{2}{*}{ df } & \multirow[b]{2}{*}{$t$} \\
\hline & & 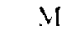 & SD &. & SD & & \\
\hline & $\int C$ & 26.2 & 3.6 & 22.1 & 4.9 & 6 & 2.39 \\
\hline \multirow[t]{2}{*}{ Oiker phobias } & $\{0$ & 25.1 & 5.8 & 250 & 6.0 & 6 & 0.08 \\
\hline & $T$ & 25.7 & 3.6 & 22.3 & 6.2 & 6 & 2.16 \\
\hline FSS & & 214.9 & 23.3 & $21+0$ & 67.0 & 6 & 0.04 \\
\hline SAS & & 599 & 14.8 & 60.1 & 154 & 6 & -010 \\
\hline I-E scale & & 43.3 & 7.1 & 40.0 & 8.0 & 6 & 1.26 \\
\hline \multirow[t]{2}{*}{ SDS } & & 54.7 & 9.4 & 52.3 & 10.3 & 6 & 0.50 \\
\hline & & \multicolumn{2}{|c|}{ Pre-test } & \multicolumn{2}{|c|}{ Post-test } & & \\
\hline \multicolumn{2}{|l|}{ Flooding/self-observation } & $\mathrm{M}$ & SD & $M$ & $\mathrm{SD}$ & $d f^{\prime}$ & $t$ \\
\hline In tito measurement & & 12.3 & 11.2 & 65.0 & 27.1 & 5 & $-4.74+$ \\
\hline \multirow{4}{*}{$\begin{array}{l}\text { Phobic anxiety scale } \\
\text { Soreet }\end{array}$} & $\int \mathrm{C}$ & 6.2 & 1.7 & 2.3 & 1.3 & 5 & $6.38_{+}^{+}$ \\
\hline & $\{0$ & 7.0 & 1.5 & 3.0 & 1.5 & 5 & $6.32_{+}^{+}$ \\
\hline & $(\mathrm{T}$ & 6.0 & 1.3 & 2.2 & 1.2 & 5 & $4.84_{+}^{+}$ \\
\hline & C & 22.8 & 5.4 & 13.8 & 6.6 & 5 & $5.81+$ \\
\hline \multirow[t]{2}{*}{ Other phobius } & $\{0$ & 23.3 & 4.3 & 14.0 & 8.0 & 5 & $4.05+$ \\
\hline & $\mathrm{T}$ & 19.5 & 6.1 & 12.3 & 3.5 & 5 & $2.78^{*}$ \\
\hline \multicolumn{8}{|l|}{ Phobic avoidance scale } \\
\hline \multirow{4}{*}{ Street } & $\int \mathrm{C}$ & 6.3 & 1.4 & 3.3 & 1.8 & 5 & $3.11^{*}$ \\
\hline & $\{0$ & 7.0 & 0.8 & 3.3 & 2.6 & 5 & $3.12^{*}$ \\
\hline & $(\mathrm{T}$ & 6.8 & 0.9 & 2.8 & 2.3 & 5 & $3.30^{*}$ \\
\hline & $\int c$ & 26.2 & 3.4 & 18.2 & 7.9 & 5 & 2.44 \\
\hline \multirow[t]{2}{*}{ Other phobias } & $\{0$ & 24.7 & 1.8 & 15.3 & 7.8 & 5 & $2.76^{*}$ \\
\hline & $T$ & 25.2 & 1.7 & 17.5 & 6.7 & 5 & 2.43 \\
\hline FSS & & 213.3 & 51.7 & 176.5 & 45.8 & 5 & $3.59 \dagger$ \\
\hline SAS & & 64.0 & 15.7 & $6+.2$ & 12.4 & 5 & -0.04 \\
\hline I-E scale & & 44.2 & 8.0 & +5.2 & +0 & 5 & -0.27 \\
\hline SDS & & 61.2 & 8.8 & 59.2 & 10.0 & 5 & 1.20 \\
\hline
\end{tabular}

\begin{tabular}{|c|c|c|c|c|c|c|c|}
\hline \multirow[b]{2}{*}{ Waiting list-control } & & \multicolumn{2}{|c|}{ Pre-test } & \multicolumn{2}{|c|}{ Post-test } & \multirow[b]{2}{*}{ df } & \multirow[b]{2}{*}{$t$} \\
\hline & & $M$ & SD & $M$ & SD & & \\
\hline In rivo measurement & & 10.0 & 7.9 & 10.0 & 8.0 & 8 & 0.00 \\
\hline $\begin{array}{l}\text { Phobic anxiety scale } \\
\text { Street }\end{array}$ & $\left\{\begin{array}{l}C \\
T\end{array}\right.$ & $\begin{array}{l}6.0 \\
5.9\end{array}$ & $\begin{array}{l}1.8 \\
1.4\end{array}$ & $\begin{array}{l}6.4 \\
6.1\end{array}$ & $\begin{array}{l}1.1 \\
1.0\end{array}$ & $\begin{array}{l}8 \\
8\end{array}$ & $\begin{array}{l}-0.77 \\
-0.55\end{array}$ \\
\hline Other phobias & $\left\{\begin{array}{l}C \\
T\end{array}\right.$ & $\begin{array}{l}18.6 \\
20.4\end{array}$ & $\begin{array}{l}6.8 \\
5.4\end{array}$ & 21.2 & $\begin{array}{l}5.0 \\
4.4\end{array}$ & $\begin{array}{l}8 \\
8\end{array}$ & $\begin{array}{l}-1.85 \\
-1.65\end{array}$ \\
\hline $\begin{array}{l}\text { Phobic avoidance scale } \\
\text { Strett }\end{array}$ & $\left\{\begin{array}{l}C \\
T\end{array}\right.$ & $\begin{array}{l}6.7 \\
6.8\end{array}$ & $\begin{array}{l}1.8 \\
1.6\end{array}$ & $\begin{array}{l}7.1 \\
7.3\end{array}$ & $\begin{array}{l}0.9 \\
0.8\end{array}$ & $\begin{array}{l}8 \\
8\end{array}$ & $\begin{array}{l}-0.80 \\
-1.64\end{array}$ \\
\hline Other phobias & $\left\{\begin{array}{l}C \\
T\end{array}\right.$ & $\begin{array}{l}26.1 \\
25.9\end{array}$ & $\begin{array}{l}5.1 \\
6.7\end{array}$ & $\begin{array}{l}27.1 \\
28.3\end{array}$ & $\begin{array}{l}3.3 \\
2.5\end{array}$ & $\begin{array}{l}8 \\
8\end{array}$ & $\begin{array}{l}-0.82 \\
-1.15\end{array}$ \\
\hline $\begin{array}{l}\text { FSS } \\
\text { SAS } \\
\text { I-F. scale } \\
\text { SDS }\end{array}$ & & $\begin{array}{r}164.9 \\
35.0 \\
42.8 \\
56.1\end{array}$ & $\begin{array}{r}40.1 \\
13.4 \\
5.1 \\
10.2\end{array}$ & $\begin{array}{r}167.9 \\
47.1 \\
41.1 \\
56.7\end{array}$ & $\begin{array}{r}39.2 \\
16.5 \\
5.5 \\
7.3\end{array}$ & $\begin{array}{l}8 \\
8 \\
8 \\
8\end{array}$ & $\begin{array}{l}-0.27 \\
-2.56^{*} \\
0.63 \\
-0.18\end{array}$ \\
\hline
\end{tabular}

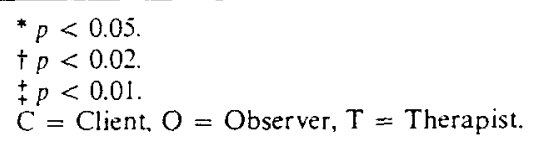


At the end of the treatment. it was shown that each of the three methods, flooding. selfobservation and flooding/self-observation, resulted in significant improvement on a number of scales, whereas the waiting-list control group showed no improvement on any variable, and even showed a deterioration on the SAS (see Table 2).

Table 3. Significant comparisons on analyses of variance (Scheffe) at the post-test

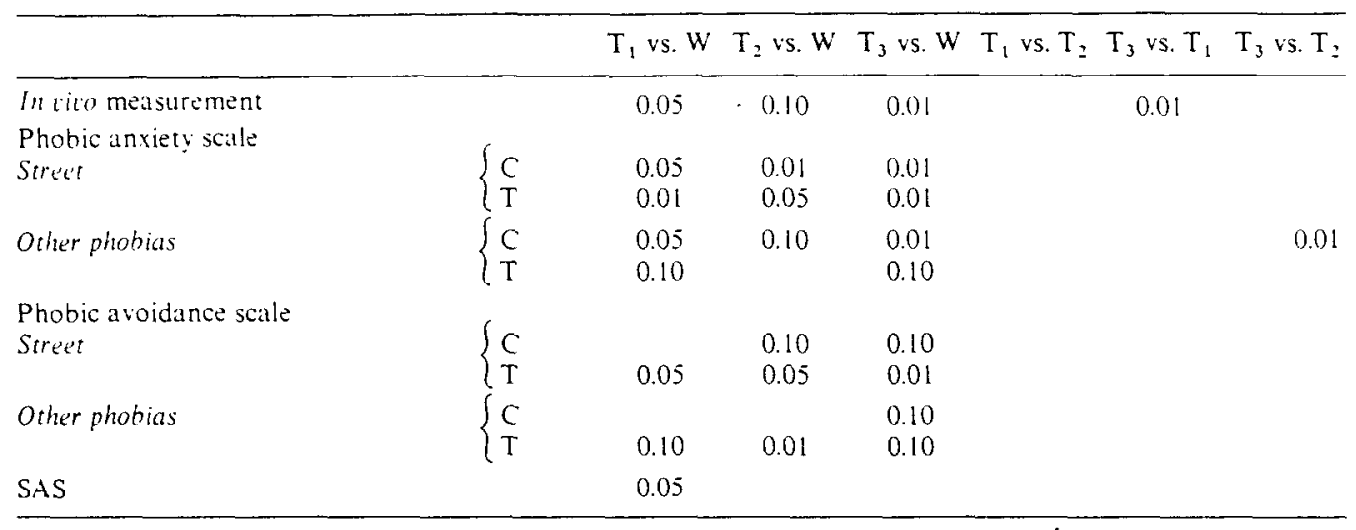

$T_{1}=$ Flooding. $T_{2}=$ Self-observation. $T_{3}=$ Flooding self-observation, $C=$ Client. $\dot{T}=$ Therapist.

Scales not shown yielded no significant differences.

In order to discover whether there were any differences between the individual conditions, an analysis of variance was applied to the change scores. At the intermediate test, no significant difference was found on any of the scales. Significant differences were, however, found at the post-test. The results of the analysis of variance and of the post-hoc analyses of Scheffe with regard to the post-test are given in Table 3.

There were significant differences on a number of variables between the treatment conditions taken individually and the waiting-list control group. No significant difference was found between flooding and self-observation.

The combined flooding/self-observation treatment proved to be more effective than flooding on the in vivo measurement $(p<0.01)$, and more effective than self-observation on the phobic anxiety scale-other phobias, as rated by the client $(p<0.01)$.

In the period of three months between post-test and follow-up, 14 of the clients received further treatment which was adapted to their specific problems. The average number of sessions per client in this period was for the flooding treatment 6.7 , for self-observation 2.8 , and for flooding/self-observation 6.8.

A comparison of the results of the post-test and the follow-up shows that only the flooding/self-observation treatment resulted in a significant improvement on the phobic anxiety scale-other phobias, as rated by the client $(t=3.029, d f=5, p<0.05)$ and therapist $(t=$ 6.445. $d f=5, p<0.01)$, and on the FSS $(t=2.610, d f=5, p<0.05)$. On the phobic anxiety scale-other phobias, as rated by the therapists, the flooding/self-observation treatment led to a significantly greater improvement than the other treatments $(F=5.41$, $p<0.02$ ).

\section{DISCUSSION}

The most important results of this investigation are that all treatment conditions resulted in a significant improvement on a number of variables, in contrast to the waitinglist control group, and that no difference in effectiveness was found between the self-obser- 
vation and the flooding treatments. In addition. the results suggest that at combined flooding self-observation treatment is more effective than each of the individual treatments. The improvement can perhaps best be demonstrated by means of the in tivo measurement: at the beginning of the treatment. the clients were able to walk outside without feeling tense for an average of $10.6 \mathrm{~min}$; at the end of the treatment. this period was on the average $10 \mathrm{~min}$ for the waiting-list control group. $46.9 \mathrm{~min}$ for the flooding group. $45.4 \mathrm{~min}$ for the self-observation group. and $65 \mathrm{~min}$ for the flooding self-observation group. Within each treatment condition. however. large individual differences existed.

At the post-test the mean improvement on the main phobia scale. as rated by the client (anxiety and avoidance combined) was 2.7 for flooding. 3.2 for self-observation and 3.5 for flooding/self-observation. In comparable previous studies with agoraphobics the mean improvement on this scale after $16 \mathrm{hr}$ of flooding in imagination and in cilo was 3.4 (Stern and Marks. 1973) and after 12 hours of flooding in vivo 2.3 and 3.2 for structured and unstructured groups respectively (Hand, Lamontagne and Marks, 1974).

The fact that no difference in effect was found between the flooding and self-observation methods is of importance for clinical practice. In the first place. this means that experiencing anxiety, such as occurs in flooding. is not a requisite for the successful treatment of agoraphobia, as self-observation results in an equal improvement. In the second place, it has been shown that agoraphobics can be helped with a minimum of intervention on the part of the therapist.

The self-observation and flooding methods differ with respect to the role played by the therapist. With flooding, it is the therapist who carries out the treatment, while the selfobservation it is the client himself: the therapist teaches the client a method of treatment, so that the client can carry out his own therapy. If a phobic patient is not regarded as someone with an isolated phobia but as someone who can be characterized by an avoidance of all anxicty-arousing situations (Andrews. 1966: Palmor. 1972), acquiring self-control ought to be very important especially for this group.

As the follow-up showed, the combined flooding/self-observation treatment produced a significant improvement on the phobic anxiety scale-other phobias and on the FSS. This could mean that in the course of the treatment the clients developed a general strategy for coping with anxiety-arousing situations. An interesting fact in this connection is that furing and after the experimental period some of the clients of their own atccord applied the same method (graded practice) in other situations than the street-for example the bus, a department store, etc.

In a number of cases the treatment produced problems. With a few clients undergoing flooding, it proved to be impossible for them to walk outside alone for $45 \mathrm{~min}$; they came back in panic after a few minutes and could not be persuaded to go out again immediately. After an experience of this kind, two of the clients decided to give up the treatment. Clients also reacted differently to flooding in the imagination. Some of them reacted extremely emotionally, while for other clients it appeared to be impossible after a few sessions to feel anxiety during flooding in the imagination, although actual walking in the street did still arouse anxiety.

Some of the clients undergoing the self-observation treatment did not send in their notes in time and had to be pressed to do so by the therapist. A few clients did not return immediately when they began to feel tense. In those cases where the client forced himself to stay outside for a long time, the distinction between self-observation and flooding in vivo becomes vague. 
In a number of cases. the client sagoraphobia appeared to play an important part in the marital relationship. In one case. the husband of a client-who had been treated successfully according to the client herself and her therapist-told the independent observer that his wife had not improved and could only be helped by him. In another case, a client was forced by her husband to give up the treatment because her therapist could make her walk outside and the husband could not make her walk outside with him. In three other cases. conjoint marital therapy was started after the post-test.

It is not clear by what mechanism flooding and self-observation operate. Self-observation and flooding as applied in this investigation do have one common factor: in both types of treatment. the client is exposed to the phobic situation in vivo. In flooding. the client's exposure to the situation is prolonged and may not be avoided. while in self-observation, the client's exposure is gradually lengthened and may be a voided. It had been suggested elsewhere (Emmelkamp. 1974) that this exposure in ciro is the essential element of the treatment. which may eventually bring about habituation.

\section{REFERENCES}

Agras W. S.. LetTeNBERG H. and BARLow D. H. (1968) Social reinforcement in the moditication of agoraphobia. Arch. Gin. Psichiat. 19, +23-427.

A voraws J. D. W. 11966$)$ Psychotherapy of phobias. Psichol. Bull. 66, 455-480.

Crowi M.. Marks I. M., AGras W. S. and Leltevberg H. (1972) Time-limited desensitization, implosion and shaping for phobic patients: A crossover study. Behal. Res. \& Therapy 10, 319-328.

EmsilkawP P. M. G. (1974) Elfects of expectancy on systematic desensitization and flooding. Europ. J. Behat, Anel. \& Hodification. (In press.)

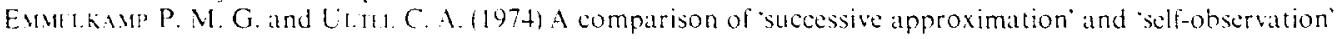
in the tratament of agoraphohiat. Behat. Therapl. 5. (lu press).

EVRALKD W. T. A. M. RIJKIN H. M. and EMMlLkAMP P. M. G. (1973) A comparison of hooding and successive approximation in the treatment of agoraphobia. Behat. Res. \& Therapy. 11, 105-117.

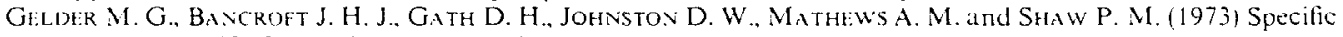
and non-specific factors in behaviour therapy. Br. J. Psichiat. 123, 445-462.

HANi I., LAMONTAGive $Y^{\prime}$, and Makks I. M. (1974) Group exposure (flooding) in vico for agoraphobias. Br. $J$. Purchiat (In press)

Minks 1. W. (1969) Four and phohias. Academic Press. Now York.

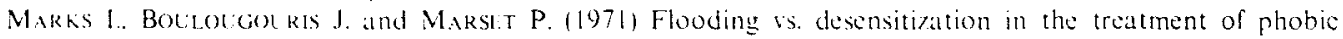
patients: a cross-over study. Br. J. Psichiat. 119, 353-375.

PALMI:R R. D. (1972) Relationship of fearfulness to locus of control of reinforcement and perceived parental be-

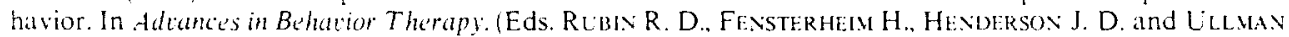
L. P.). Academic Press. New York.

Rotri: J. B. (1966) Generalized expectancies for internal vs. exter nal control of reinforcement. Psychol. Monogy. $80,1-28$.

STIR: R. and MarkS I. (1973) Bricf and prolonged tlooding: a comparison in agoraphobic patients. Areh. Gen. Prichiat. 28, 270-276

WarsoN J. P. and Marks I. M. (1971) Relevant and irrelevant fear in hooding: a cross-over study of phobic patients. Behar. Therapl: 2, 275295.

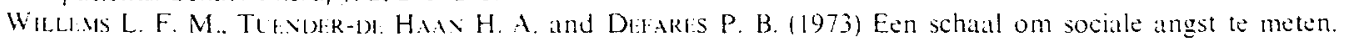

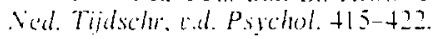

Wolpe J. and LANG P. J. (1964) A fair survey schedule for use in behavior therapy. Behat. Res. \& Therapt. 2. $27-30$.

Zuvi W. W. K. (1965) A self-rating depression scale. Arch. Gen. Psichiat. 12, 63-70. 